\title{
Evaluation of Antimicrobial Activity of Mineral Trioxide Aggregate (MTA)
}

\author{
Mahmoud Y Taha \\ BVM, MSc, PhD (Assist Prof)
}

Maha M Al-Bazzaz

BDS, MSc (Assist Lect)

Ennas Y Shehab

BSc, MSc (Assist Lect)

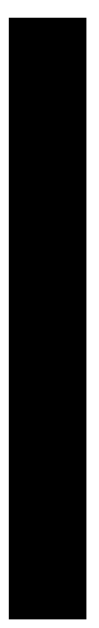

\begin{abstract}
Aims: To evaluate the antimicrobial activity of MTA against selected microorganisms compared with a widely used root end filling materials. Materials and methods: Fifteen mm discs of MTA, GIC and Amalgam were prepared and three types of microorganisms; two bacteria and one fungus, were grown in $4 \mathrm{ml}$ of brain heart infusion broth for $18 \mathrm{hr}$. Then $0.5 \mathrm{ml}$ of each growth was spread over selected media (three plates for each sample) and the discs were applied on the agar, incubated for 24-48 hr and the zone of inhibition was measured. Results: Amalgam did not demonstrate any antimicrobial activity, whereas MTA showed antimicrobial effect against all tested microorganisms and was highly significant. GIC showed antibacterial activity comparable to MTA but failed to produce antifungal effect. Conclusions: MTA demonstrated antibacterial and antifungal effect, while GIC showed only antibacterial activity, whereas Amalgam did not show any activity.

Keywords: antimicrobial activity, MTA

Taha MY, Al-Bazzaz MM, Shehab EY. Evaluation of Antimicrobial Activity of Mineral Trioxide Aggregate (MTA). Al-Rafidain Dent J. 2009; 9(2): 216 - 219.

Received: 9/3/2008 Sent to Referees: 9/3/2008

Accepted for Publication: 25/5/2008
\end{abstract}

\section{INTRODUCTION}

Microorganisms are regarded as the main etiological factor in pulpal and periapical diseases and their elimination during root canal treatment by instrumentation, irrigation and intracanal medication is essential ${ }^{(1,2)}$. However, even after these procedures, microorganism might still be found inside root canal ${ }^{(3)}$. Therefore, root filling plays an essential role in the control of reinfection by residual organisms through antimicrobial activity of endodontic sealing materials ${ }^{(4)}$.

An ideal root end filling material should adhere and adapt to the dentinal walls of root end preparation, preventing leakage of microorganisms and their byproducts into periradicular tissues in addition to its biocompatibility and insolubility in tissue fluids ${ }^{(5)}$.

Numerous materials have been used as root canal end filling materials as gutta percha, zinc oxide-eugenol, composite resin, gold foil and glass ionomer cement
(GIC). However, no materials have been found to have all ideal properties of root end filling materials ${ }^{(6)}$.

An experimental material, mineral trioxide aggregate (MTA) was developed to seal off all pathways of communication between root canal system and external surface of tooth ${ }^{(7)}$. It has been shown that MTA posses biological and physical properties of an ideal filling materials ${ }^{(8,9)}$.

The current study is to evaluate the antimicrobial activity of MTA against selected microorganisms and comparing the results with a widely used root end filling materials such as amalgam and glass ionomers cement.

\section{MATERIALS AND METHODS}

Preparation of Sealer Filling Materials:

Mineral trioxide aggregate (ProRoot; Tulsa Dental, USA) was prepared by mixing three parts powder with one part aqueous solution ${ }^{(10)}$. After 30 seconds, the mixture should exhibit putty-like consistency. 
Then MTA should immediately be placed in a mold which is a prefabricated a celluloid tablet sheath to obtain a uniform disk like of $15 \mathrm{~mm}$ diameter.

Glass ionomer cement (Megadenta Gmbit Dental product, Radeberg, Germany) was mixed according to the manufacturer instructions and applied in a putty-like consistency using the same method in MTA.

Aprecapsulated high copper, nongamma 2 alloy (Viva cap, Vivadent, Ets. Germany) was used. It was triturated with mechanical amalgamator (Silamat, vivadent, Schoan, Liechtestien, Germany) for 10 seconds and immediately condensed into the corresponding celluloid sheath cavities to obtain a disc shape of the same dimension as for MTA and GIC.

\section{Antimicrobial Assay}

The antimicrobial effect was studied using disk diffusion method ${ }^{(11)}$. Three microorganisms were used in this study, S. aureus as gram positive, $E$. coli, as gram negative and C. albicans as fungi. These microorganisms were grown in $4 \mathrm{ml}$ of brain heart infusion broth to enhance their growth at $37 \mathrm{C}^{0}$ for $18 \mathrm{hr}{ }^{(12)}$. Then three replicates plates of blood agar for $S$. aureus, MacConkey agar for E. coli and Sabouraud agar for C.albicans were inoculated each with $0.1 \mathrm{ml}$ of selected microorganism and spread over the plate ${ }^{(13)}$. Then discs of selected root end filling materials were applied to the surface of the agars and incubated at $37 \mathrm{C}^{\circ}$ for $24 \mathrm{hr}$ (for bacteria) and $48 \mathrm{hr}$ (for fungi) and the zone of inhibition was examined.

\section{RESULTS}

The antimicrobial activity of the root end filling materials against different microorganisms is shown in Figure 1. Amalgam did not demonstrate any antimicrobial activity, whereas GIC and MTA showed clear antimicrobial activities against bacteria. The antifungal effect was clear in MTA compared to amalgam and GIC.

Statistical analysis using Duncan's Multiple Range Analysis is shown in Table 1 . The antibacterial activity of MTA and GIC is highly significant compared to Amalgam $(p<0.01)$, whereas the antifungal activity of MTA is highly significant compared to Amalgam and GIC $(p<0.01)$.

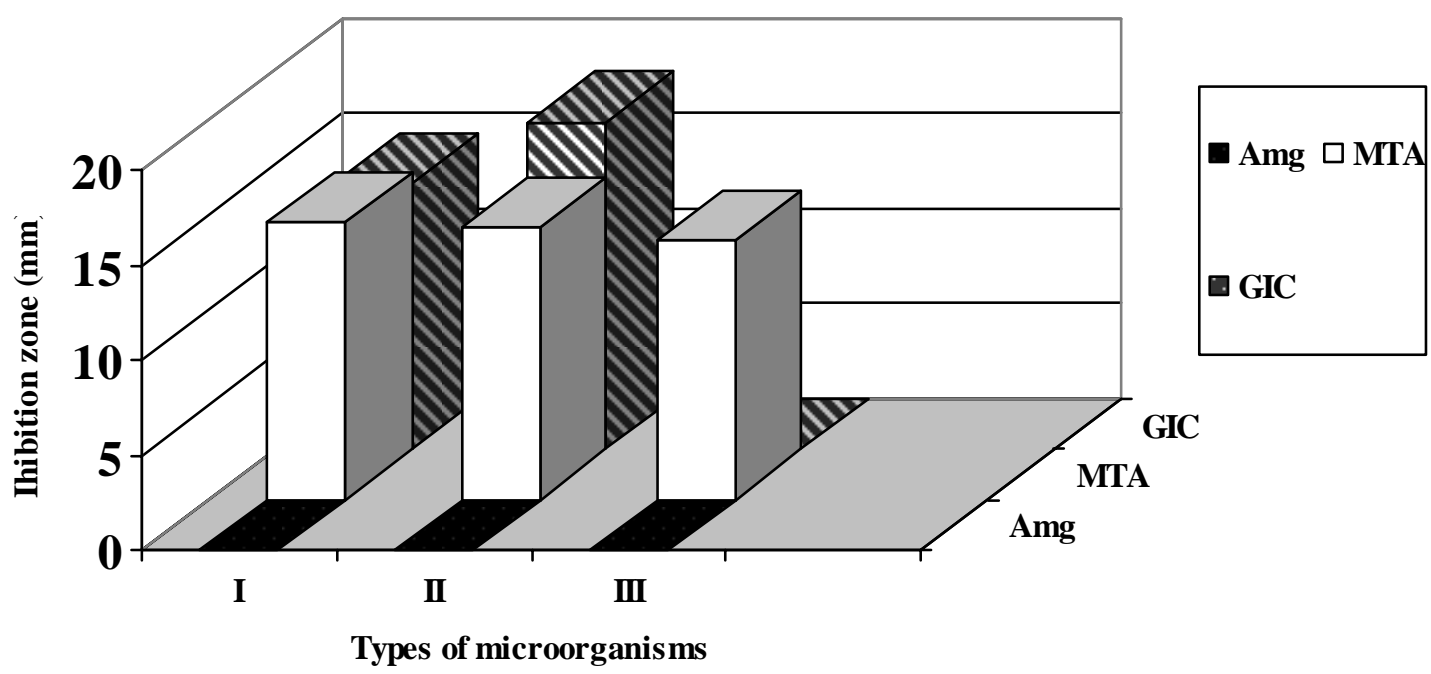

Amg: Amalgam; GIC: Glass Ionomer Cement; MTA: Mineral Trioxide Aggregate; I: E.coli; II: S.aureus; III: C. albicans.

Figure (1): Histogram of Mean zone of inhibitions of different root end filling materials against different microorganisms. 
Table (1): Duncan's Multiple Range Analysis of Mean zone of inhibition.

\begin{tabular}{lllllll}
\hline & \multicolumn{5}{c}{ Microorganisms } \\
\cline { 2 - 7 } \multicolumn{1}{c}{ Sealers } & E. coli & \multicolumn{5}{c}{ S. aureus } \\
\hline Amalgam & 0 & A & 0 & A & 0 & A bicans \\
GIC & 14 & B & 17.3 & B & 0 & A \\
MTA & 14.6 & B & 14.3 & B & 13.6 & B \\
\hline
\end{tabular}

Different letters means significant $p<0.01$.

\section{DISCUSSION}

A variety of root end filling materials have been used for a long time. The development of material that meets an ideal root end filling material is a goal of most dental companies. MTA is a new generation that has been shown to possess biological and physical properties of an ideal root end filling materials. It has a superior sealing ability ${ }^{(7)}$, less cytotoxic ${ }^{(8)}$ and biocompatible in animal studies. ${ }^{(9)}$

The present work was conducted to evaluate the effect of MTA on a selected microorganisms compared to other root end filling materials. The study extends other studies which demonstrated different antimicrobial effects of MTA ${ }^{(8,15-18)}$.

Based on the results of this study, it appears that Amalgam did not demonstrate any antimicrobial activity against tested microorganisms. This result is comparable with others ${ }^{(19)}$. Other studies demonstrated antibacterial effect of Amalgam (20-22). This disagreement could be attributed to the available nutrients, level of oxygen, method of evaluation and different laboratory set up ${ }^{(19)}$. The method used to study antimicrobial activity was agar diffusion method. Different factors may affect the reading of the results including type of medium, microorganisms, amount of inoculum and reading point of zone of inhibition ${ }^{(18)}$.

The antimicrobial activity of MTA in this work was clear against tested bacteria and fungi. Others demonstrated no activity of MTA against S.aureus, E. coli and C. albicans, ${ }^{19,23)}$ although MTA was the same that used in the experiment. The possible explanation for such differences is the strain of microorganisms used and method of measuring antimicrobial activity.

\section{CONCLUSIONS}

MTA showed antimicrobial activity against tested microorganisms similar to
GIC except for C.albicans, while Amalgam failed to show any effect.

\section{REFERENCES}

1. Kakehashi S, Stanley HR, Fitzgerald RJ. The effect of surgical exposure of dental pulps in germ-free and conventional laboratory rats. Oral surg Oral Med Oral Pathol, 1965; 18: 340-348.

2. Moller AJ, Fabricius I, Dahlen G, Ohman AE, Heyden G. Influence on periapical tissues of indigenous oral bacteria and necrotic palp tissue in monkeys. Scand J Dent res, 1981; 89: 475-484.

3. Byström A, Sundquist G. Bacteriologic evaluation of the effect of $0.5 \%$ sodium hypochlorite in endodontic therapy. Oral surg Oral Med Oral Pathol, 1983; 55: 307-312.

4. Grossman L. Antibacterial effect of root canal cements. J Endod, 1980; 6: 594597.

5. Gartner AH, Dorn SO. Advances in endodontic surgery. Dent Clin North Am, 1992; 36: 357-378.

6. Chong BS, Pitt Ford TR, Wodson TF. The adaptation and sealing ability of light- cured glass ionomer retrograde fillings. Int Endod J, 1991; 29: 223-232.

7. Torabinejad M, Watson TF, Pitt Ford TR. Sealing ability of a mineral trioxide aggregate when used as a root end filling materials. J Endod, 1993; 19: 591-595.

8. Torabinejad M, Hong CU, Pitt Ford TR, Kettering JD. Cytotoxicity of four root end filling materials. J Endod, 1995; 21: 489-492.

9. Torabinejad M, Hong CU, Pitt Ford TR, Mckendry DJ, Abedi HR, Miller DA. Histologic assessment of mineral trioxide aggregate as root end filling in monkeys. J Endod, 1997: 23: 225-228.

10. Torabinejad M, Chivian N. Clinical applications of mineral trioxide aggregate. J Endod, 1999; 25: 197-205. 
11. Vandepitte J, Enghack K, poit P, Heuk C. Basic laboratory procedures, In clinical bacteriology, 1991.

12. Estrela C, Riberio RG, Estrela CR, Pecdra JD, Sousa-Neto MD. Antimicrobial effect of $2 \%$ sodium hypochlorite and $2 \%$ chlorhexidine tested by different methods. Braz Dent J, 2003; 14: 1-8.

13. Minwah B, Hassuni MK, Taha MYM. Microbial status of root canals and chronic priapical lesions. Iraqi Dental J. 2001; 28: 197-218.

14. Prescott LM, Harley JP, Klein DA. Microbiology, $3^{\text {rd }}$ Ed; London, Brown, 1996.

15. Mohammadi Z, Modaresi J, Yazdizadein M. Evaluation of the antifungal effect of mineral trioxide aggregate materials. $\mathrm{Au}$ st Endod J, 2008; 1-3.

16. Camilleri J, Pitt Ford TR. Mineral trioxide aggregate; a review of the constituents and biological properties of the materials. Int Endod J, 2006; 39: 747754.

17. Al-Nazhan S, Al-Judai A. Evaluation of antifungal activity of mineral trioxide aggregate. J Endod, 2003; 29: 826-827.
18. Sipert CR, Hussne RP, Nishiyama CK, Torres SA. In vitro antimicrobial activity of fill canal, sealapex, mineral trioxide aggregate, protland cement and endorez. Int Endod J, 2005; 38: 539-543.

19. Torabinejad M, Hong CU, Pitt Ford TR, Kettering JD. Antibacterial effect of some root end filling materials. J Endod, 1995; 21: 403-406.

20. Glassman MD, Miller IJ. Antibacterial properties of one conventional and three high copper dental amalgams. J Prosthet Dent, 1984; 52: 199-203.

21. Orstavik D. Antibacterial properties of and element release from some dental amalgam. Acta Odontol Scand, 1985; 43: 231-239.

22. Tobias RS, Rippin JW, Browne RM, Wilson CA. A further study of antibacterial properties of dental restorative materials. Int Endod J, 1988; 21: 381-392.

23. Estrela C, Bammann LL, Estrela CR, Siliva RS, Pecora JD. Antimicrobial and chemical study of MTA, Portland cement, calcium hydroxide paste, sealapex and dycal. Braz Dent J, 2000; 11: 3-9. 